\title{
WHAT SITUATIONS CAUSE CRUCIAL FINANCIAL DECISIONS WITHIN SOCIAL BUSINESSES?
}

\section{Duháček Šebestová, J., Krejčí, P., Rylková, ž.}

Jarmila Duháček Šebestová / Silesian University in Opava, School of Business Administration, Department of Business Economics and Management, Univerzitní náměstí 1934/3, Karviná, 733 40, Czech Republic. Moravian Business College Olomouc, tř. Kosmonautů 1288/1, 77900 Olomouc, Czech Republic. Email: sebestova@opf.slu.cz.

Petra Krejči / Silesian University in Opava, School of Business Administration, Department of Business Economics and Management, Univerzitní náměstí 1934/3, Karviná, 733 40, Czech Republic. Email: krejci@opf.slu.cz.

Žaneta Rylková / Silesian University in Opava, School of Business Administration, Department of Business Economics and Management, Univerzitní náměstí 1934/3, Karviná, 733 40, Czech Republic. Email: rylkova@opf.slu.cz.

\begin{abstract}
The growing uncertainty in today's business environment has a significant influence on social business's behaviour. Those enterprises could rely on public support in the past, but nowadays, they have to find a way to be more responsible about their social activity and be financially independent on public resources. Based on this theoretical background, the paper's main goal was to find a set of factors that influence crucial financial decisions within a crisis. When social businesses create an optimal financial portfolio to be financially sustainable, primary research was conducted. A sample of 57 social businesses was asked about their financial strategy. The main research goal was to compare a change before and after the first wave of the Covid-19 pandemic situation in 2020. This case has shown current financial thinking and preparedness for unusual or crises. A mixed research approach was chosen due to a limited number of respondents. The overall results found that those businesses prefer to use the current strategy (42\%) in crisis, and they limit investments to survive in that situation, except marketing investments (16\%).

Implications for Central European audience: At the theoretical level, our study shows social enterprise concepts in the Central European context, which differs somewhat from the already established definition of mainly Anglo-Saxon and American authors. At the same time, it combines knowledge about the use of financial planning in this segment. The study results show that financial planning is essential in these companies because it can achieve social goals. A discussion would be opened on how to raise awareness of the preparation of the strategy. Alternatively, how to strengthen the financial literacy of managers or representatives of these entities.
\end{abstract}

Keywords: financial decision; investments; profit; social business JEL Classification: L26, L31, M21 


\section{Introduction}

Very dynamic and intense changes in the business ecosystem and the need for obtaining and maintaining a competitive position require social enterprises and non-profits to determine the most appropriate strategies (Borocki et al., 2019). It relates to all the companies, regardless of size, sector of activity, location, and profit orientation. Based on current external and internal factors, organisations should make financial decisions to succeed and maintain their market position to be sustainable. However, non-profits in developing countries have some limitations, therefore why non-profits are run differently. Those limitations include insufficient financial resources, lack of experience in specialised areas and management, concentration on the local community. One should remember that all organisations face a very competitive environment due to the globalisation process and new technologies (Moravcikova \& Kliestikova, 2017), the growing role of CSR in all operations (Rahman et al., 2020), inter-firm cooperation, both bilateral and multilateral (Kozma, 2017; Sebestova et al., 2017).

In the last decade, the social economy has also managed a much stronger position on the European level. The social economy was presented and supported by European Commission in 1989 (European Commision, 1989). According to DG Enterprise (European Commision, 2011), the social economy consists of cooperatives, mutual societies, associations, foundations, and social enterprises (Dohnalová, 2009). Social enterprises have a long history, but they have had a higher weight and need for society in recent years. Political representation, the media, and the non-profit sector turn their attention to social enterprises with the expected solutions to civil society's current environmental and social problems (Christie \& Honig, 2006). Social entrepreneurship has been supported by the growing interest of governments and the general public since the early 1990s. This situation is a rapidly evolving field that has broadened the concept of entrepreneurship by including (and in some cases emphasising) the "social dimension" of entrepreneurial activities (Trivedi, 2010). It thus emphasises the social mission of entrepreneurship and combines the creation of social value with commercial means.

Social entrepreneurship can generally be seen as a process of creating value by combining resources in new ways that are primarily designed to explore and seize opportunities to create social value by stimulating social change or meeting social needs (Mair \& Martí, 2006). Using business for social purposes rather than for profit, or how business profits can be used for social purposes, has long been a significant concern of practice and policy (Fowler, 2000; Harding, 2004; Roundy \& Bonnal, 2020).

It is worth mentioning that there are differences in national contexts due to legislation and tradition across Europe and other countries. Significant differences could be seen in differences between North American and European social entrepreneurship (Bacq \& Janssen, 2011; Lortie et al., 2017). When the definition is not unified, we chose some important statements, which supports a connection between social and entrepreneurship activities. Hervieux et al. (2010) define social entrepreneurship as: "a business process initiated by social entrepreneurs with social goals to create social value, where social entrepreneurship results in social enterprises; including social enterprises using commercial funds and in the form of non-governmental organisations (NGOs). "Following that, those 
enterprises operate with limited resources. They have to provide additional business activity as summarised in another definition: "Social enterprises can be defined as organisations with the explicit goal of helping the community, a group of citizens founds them, and their resources are limited. They are based on independence and are subject to economic risks due to the subject of their socio-economic activities." (EMES, 2016).

To conclude, it seems to be so essential to have a social goal and financial resources, followed by business activities like: "A social enterprise is an enterprise that has been created to support a social purpose financially." (NESsT, 2019).

In addition to that, non-profits and social enterprises are nowadays under the influence of the external environment (donors, supporters, companies) to clarify their vision, mission, core values to be more professional and easy to follow by shareholders. This professionalisation gives more responsibility to social entrepreneurs to be decisive and prepared in a strategic way of thinking to present their social impact to the public. (Gutterman, 2021; Lin-Hi et al., 2015; Pope et al., 2018)

Undoubtedly, social entrepreneurship will play an increasingly important role in future social and economic development. On the one hand, profit-maximising companies do not avoid environmental problems and resource scarcity. Historically, this complex of problems falls into the sphere of non-governmental, non-profit organisations or the third, voluntary or social sector, which works differently in different economies worldwide. Due to limited financial resources, governments are forced to close gaps in social services, creating space for social and community development goals.

\section{Commercial Activity by Social Enterprises}

Social entrepreneurship is very often mentioned as a hybrid combination of the non-profit sector and entrepreneurial activity. In this context, Battilana and Lee (2014) emphasise the differences between traditional entrepreneurs, social entrepreneurs and non-profit organisations. It should be emphasised here that traditional non-profit organisations are usually funded from external sources (by the state or donors) and do not take the business risk, and usually do not generate profit for their activities.

In contrast, existing social enterprises can take non-profit and use commercial legal forms. It is up to the founder what legal forms it will use and its financial resources and support. A social enterprise should make a profit like any other. The difference between profit companies and social enterprises is then in the distribution of profit. In the commercial world, the owner can use the profit to his advantage. In the world of social enterprises, there is a different distribution of profits. Most of the profits, or even the whole, are both reinvested in a social enterprise and used for activities closely connected with social goals.

According to Durieux and Stebbins (2010), we can see the meaning of social entrepreneurship in three primary areas, namely:

- An area of motivation where the primary motivation (Groot \& Dankbaar, 2014) can be an urgency to solve a social problem or compassion for the target group. Alternatively, conversely, the motivation may be to make a profit to support a selected area. 
- In an area of the organisation, it is necessary to have skills in organising the activities of a company, creating a profile, and determining the legal form of a social enterprise.

- It is followed by an area of influence on society, where, like any company, it must build its networks and look for like-minded groups and sources of its support.

Based on this, social enterprises exist most often as (i) social entrepreneurship as a business with a social purpose, (ii) social entrepreneurship and social enterprises based on non-profit principles, (iii) entrepreneurship based on the social economy and social enterprises that integrate work (integration enterprises), (iv) social entrepreneurship as social entrepreneurship (Gawell, 2014).

Following that, we could use the term "hybrid social enterprise" when social enterprise fulfils social goal and purpose, but it behaves like a commercial subject on the market to be successful, which makes a difference from non-profits (Paksiova, 2017; Santos et al., 2015; Zott et al., 2011).

\subsection{A need for financial planning and decision-making - when and why?}

Several existing discussions exist to compare and contrast the correlation between social and financial performance as a part of corporate responsibility or corporate social responsibility - CSR (Lodsgård \& Aagaard, 2017). First of all, is worthy of mentioning that the CSR concept plays a significant role in innovativeness and organisation performance when it could have two layers. The first layer is organisation oriented and the second on his marketoriented. Both layers help organisations find a competitive advantage in selected sectors or cross-sector cooperation (Lahtinen et al., 2018; Saeed et al., 2015). Financial decisionmaking means that socially-oriented activities are performed by social businesses whose primary goal is a social benefit. Unfortunately, those activities are closely connected with the risk, and sometimes they are profitable and sometimes without any value-added. This factor is typical for those social enterprises in contrast to business-oriented companies (Nijhof \& Jeurissen, 2010).

Some social enterprises can earn a sufficient profit to supply their activities because they have a good investor base. On the other hand, they could have a proper portfolio of products that customers are interested in and are prepared to pay a premium price like green products, organic food. On the other hand, they could supply other services (social counselling, support, care) for indigent clients who cannot pay or the payment is from public resources. Many social enterprises survive only through the largesse of product portfolios and various financial resources or financial activities like crowdfunding, fundraising and charity events (BuggLevine et al., 2012).

Santos et al. (2015) presented four types of hybrid organisations, which could operate on the market and they could transfer their activities to an online environment:

- Market Hybrid is the model close to pure commercial models, with the difference is that the organisation adopts a social mission, especially in essential health and social care. 
- Blending Hybrid is the organisations that serve to pay clients who are also the beneficiaries of their societal mission. They could rely on external partners and cooperation. They use mixed financial resources.

- Bridging Hybrid are organisations that focus on clients and beneficiaries from different groups and manage them together (disabled people and people without disabilities). They also use mixed financial resources.

- Coupling Hybrid is an organisation with work integration, social enterprise and service providing for paying clients.

The primary financial sources of non-profit organisations are, in addition to potential income from business activities, income from the state budget, income from self-governing territorial units, subsidies, membership fees, income from public collections, donations, operating contributions from the founder. These sources of income vary according to the specific type of non-profit organisation. Although non-governmental, non-profit organisations need strategic management, and they do not implement it as often as traditional companies due to the low capacity of non-profit organisations in human and financial resources. Nevertheless, it has occurred in recent years in the Czech Republic to significant progress in this area. Šedivý and Mendlíková (2011, p. 28) identified some of the most critical strategic milestones in which non-profit organisations need to plan strategically:

There are solid external influences that affect the non-profit organisation, such as changes in subsidy policy, economic crisis, diversion of some essential donors, and legislation change. There is a change in the internal environment in a non-profit organisation (replacement of statutory bodies or senior employees) which shapes ideas about the operation and future development of the organisation. If the organisation succeeds in fulfilling its mission and vision, which is in the vast majority rather than a theoretical point, it is necessary to plan its future development strategically. The basis of any strategic planning is to analyse the current state and define the mission and vision of the organisation because the vision and mission derive its operation and future planning within sustainable financial planning.

Many social enterprises are currently struggling with existential problems. Some social enterprises or non-profit organisation cannot provide their services due to government restrictions due to pandemic Covid-19 (e.g. group therapies, family counselling, educational and additional paid leisure activities). At the same time, some have significantly increased the number of clients (hospice care or organisations helping victims of domestic violence) and suffer from a lack of nurses or other staff. The increased costs of purchasing protective equipment and disinfection or the lack of staff due to illness or childcare (due to quarantine and school closures) are also significant problems. The inability to provide their services inperson to clients (families, seniors and others) has led some organisations to move to an online environment, where they often encounter a lack of obsolescence of IT technology (Popescu \& Popescu, 2019).

Social enterprises also record loss of income from the use of services from clients (due to closures) or various ancillary activities (e.g. due to market failure and the closure of generous businesses), and financial contributions from corporate donors are also at risk. All this disrupts the activity and stability of the social economy. Social enterprises were providing services, such as laundries, are losing contracts (due to closed hotels and boarding houses) and significantly shortfall sales. However, there are also problems with the supply of materials for producing products or the inability to supply catering, operating cafes in which people with 
disabilities are employed. Unfortunately, all these problems are also related to the possible future dismissal of disabled employees who will not find another job in the labour market or find it very difficult. On the other hand, they were social enterprises active in online business before the Covid-19 pandemic situation, and this proactive approach helped them survive hard times.

Based on the previous literature review, we found out that they are no existing studies dedicated to the decision-making behaviour of social entrepreneurship within crisis when the Covid-19 pandemic situation represents one example. It is why we set the main research question: Which factors affect financial decisions in social businesses? The results we will present in the form of interview evaluation conducted with managers of social businesses in the Czech Republic in the form of two hypotheses, supporting the main research question as:

H1: During the Covid-19 pandemic situation, social entrepreneurs reinvest more profit into business activities.

Crucial decision-making is thus connected with the mission integrity problem, wherein social enterprises must take into account the social goal and generate profit at the same time. Suppose responsible managers or founders are sufficiently motivated and involved in the operation of a social enterprise. In that case, they prefer the goal before generating a profit, even at the cost of using the profit to refinance other company activities (Besley \& Ghatak, 2017; Katz \& Page, 2010; Martin \& Osberg, 2007). The economic benefit should be achieved through three objectives, namely: profit should be used primarily for the development of a social enterprise or for the fulfilment of public benefit objectives, at least the minimum share of profit of products and services in total revenues, the elimination of economic risks and reduction of asset management. The recommended indicator by Palová and Šebestová (2020) was the rate of reinvestment of profit. The level of the ideal indicator was set at $51 \%$ when it is again based on the principles of the social enterprise TESSEA when it should be a minimum of $51 \%$ of profits reinvested in the social enterprise (or non-profit organisation). Another way, how to evaluate economic impact is if it had no strategic plans at all. The last economic indicator measured was an indicator that indicated whether the company had in its foundation documents the transfer of the liquidation balance in case of its dissolution to another social enterprise or public benefit organisation or municipality. However, we assume that the relationship between social goals and profit will be strengthened in pandemic situations. And the manager or owner will want to run the company by reinvesting more than the expected profit.

\section{H2: Social entrepreneurs changed their financial planning due to pandemic situations.}

The non-profit organisation SANEK Ponte surveyed strategic planning in 2015 and received a surprising result. When $70 \%$ of respondents from non-governmental, non-profit organisations in the Czech Republic had a strategic plan prepared in some form (comprehensively or in parts). A significant change compared to the previous year when just over $50 \%$ of the organisations surveyed were strategic planning. This change was undoubtedly helped by financial support and some pressure from project sponsors funded by the European Social Fund (especially the Human Resources and Employment Operational Program) and the Norwegian and Swiss funds, which emphasised improving the institutional management of NGOs. 
Pro-social motivation should lead to the fact that the financial plan should be adjusted in the overall strategy so that social entrepreneurship is sustainable even in the conditions of a pandemic. This situation will be an example of when social enterprises make crucial decisions. They do not make continuous changes but react adaptively to changing conditions for social entrepreneurship, which should be verifiable research results (Bénabou \& Tirole, 2010).

\section{Methodology and Data}

A combination of primary and secondary research methods was needed to acquire relevant information in social enterprises and their financial decision-making activity within a crisis (Mulgan, 2006; Tucker, 2014). It was difficult to ascertain the exact number of social enterprises in the Czech Republic, but Krejčí and Šebestová (2018) and Duháček Šebestová and Krejčí (2021) estimated there are more than 200 social enterprises in the country. These social enterprises can be classified by industry, their primary focus, business location or target group. The number of social enterprises in the Czech Republic has increased significantly between 2010 and 2018 (2010-68, 2018-211 entities), and according to the 2021 directory of social enterprises (CSP 2021), there were 171 social enterprises in the Czech Republic with 306 branches and 3,904 employees. However, the Czech Social Entrepreneurship portal is only a voluntary register. Due to its voluntary nature, not all social enterprises and social integration enterprises may be listed there. Nevertheless, as can be seen from the lower number compared to 2018, the Covid-19 pandemic also reduced their number. Previous pilot case studies in social enterprises focusing on innovation or supporting minority groups have shown that a larger sample of enterprises is needed to determine how they use funding and how they make decisions, indicating the originality of research and thematic separation from previously published works.

The primary research with the owners of all types of social enterprises had to be carried out with at least a total sample of 57 social enterprises randomly selected in the Czech Republic. With 171 social enterprises (33\%) in the Czech Republic officially registered on the TESSEA platform (providing Czech Social Entrepreneurship portal), the sample size was representative of the Czech Republic's general population of officially registered entities (Cavana et al., 2001).

The study's limitations can be seen in the validation of results, where they describe the subjective opinion and evaluation of each respondent (a social business owner). This choice was appropriate for the chosen research problem: identifying different financial behaviour within crisis situations and profit reinvestment when they are meeting an idea of social enterprises (a minimum of $51 \%$ of profit back to enterprise).

During the interviews conducted on the phone (due to the current Covid-19 situation in 2020/2021), the managers explored their primary motives for providing their social enterprise and expressed their view on financial planning ad decisions. Secondly, the entrepreneurs evaluated and answered opened and semi-opened questions focused on their financial planning, reasons for investments and their financial actions affected by the Covid-19 situation. The interview consisted of eight main questions (max. 30 minutes) when entrepreneurs were asked to compare and contrast their behaviour in financial planning like: 
- Main motives to reinvest profit (as they mentioned or some possible answers were given).

- The financial behaviour of each entrepreneur before/during Covid-19 (which segments for reinvestments they prefer, the scale $0 \%, 20 \%, 40 \%, 60 \%$...was given).

- Investment portfolio description (question focused on segments like HR, equipment, marketing and others).

- The main strategy of investment (semi-opened question to find the decision making direction).

Data sample description. The findings presented here are founded on the authors' interpretation of in-depth interviews with social enterprises owners. The sample consists of 57 respondents in this study, who dedicated their time for the interview based on the phone call. One call lasts 20 to 30 minutes on average. The leading group of respondents were men $(56.9 \%)$. When we focused on their experience, not only in social businesses, the majority of them have experience more than 20 years (30.9\%), 11 to 20 years (19.5\%), 4 to 10 years $(38.5 \%)$ and the shortest experience - till three years $(11 \%)$. This sample represents people with long business experience, so they have the competencies to evaluate precisely the current situation.

Data sample evaluation. Basic statistical methods evaluated dataset. We used a percentage share to show the significance of each element, which was tested by Cramer $V$ coefficient to describe a relationship between two nominal variables when by convention, the range of $V=$ 0.1 to 0.3 is considered as the weak effect, then 0.3 to $0.5=$ middle-sized effect, and $>0.5=$ strong. A significance was tested on the $p$-value of 0.05 . (Cohen, 1988).

\section{Results and Discussion}

Investment activities and decision making in financial management are closely related to the company's survival in a globalised market and with competitiveness, which is reflected explicitly in the continuous process of the improvement of goods and services as well as fundraising processes and the economic potential of social enterprises within a crucial situation, especially crisis. To answer the main research question, we evaluate the main decision-making factors, influenced financial management at first (Table 1). Cramer's $\mathrm{V}$ coefficient statistically evaluated all factors at significance $p$-value $=0.05$.

As illustrated in Table 1 above, the main motives for generated profit investment are extra benefit added to yields (87.7\%), payback period (82.5\%) and financial ratios $(70.2 \%)$. Surprisingly, the managers are not interested in attractive rates in banks (54.4\%). These results confirm logical and rational steps in crucial decision-making when the bank offer is not attractive to investors. It seems that the behaviour of managers is most economical, not influenced by the social goal of their enterprises. On the contrary, other factors were found as statistically significant as tax deductions (Cramer $V=0.575$, Sig. 0.05), financial ratios (Cramer $V=0.429$, Sig. 0.05) and interest rates in the bank (Cramer $V=0.369$, Sig. 0.1). The managers have a piece of knowledge about their limited financial resources to affect their behaviour (Zott et al., 2011). 
Table 1 | Main motives for profit investments

\begin{tabular}{ccccc}
\hline & \multicolumn{2}{c}{ Sentiment } & \multicolumn{2}{c}{ Evaluation } \\
\hline $\begin{array}{c}\text { Factor } \\
\text { Interest rate in }\end{array}$ & No & Yes & Cramer V & Sig. \\
bank & $54.4 \%$ & $45.6 \%$ & $0.369^{* *}$ & 0.100 \\
$\begin{array}{c}\text { Payback period } \\
\text { Tax deductions }\end{array}$ & $17.5 \%$ & $82.5 \%$ & 0.147 & 0.872 \\
$\begin{array}{c}\text { Extra benefits to } \\
\text { yields }\end{array}$ & $12.1 \%$ & $58.9 \%$ & $0.575^{*}$ & 0.001 \\
$\begin{array}{c}\text { Competitive } \\
\text { advantage }\end{array}$ & $33.9 \%$ & $87.7 \%$ & 0.269 & 0.387 \\
Financial ratios & $29.8 \%$ & $66.1 \%$ & 0.316 & 0.231 \\
\hline
\end{tabular}

Source: author's calculations. ${ }^{*}$ significance on $p$-value $=0.05,{ }^{* *}$ significance on $p$-value $=0.1$.

Secondly, the evaluation of investment behaviour was made regarding total profit allocated in the named segment in the past. (Table 2).

Table 2 | Investment behaviour of respondents - preference ( $\mathrm{N}=57)$

\begin{tabular}{|c|c|c|c|c|c|c|c|c|c|}
\hline 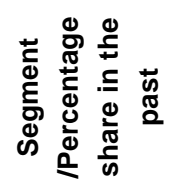 & ஃ̊ & ○े & ঃ̊ & ○̊ & ○̊ & ○̊ & 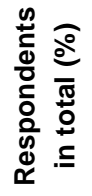 & 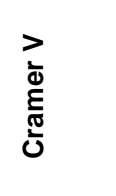 & क் \\
\hline $\begin{array}{c}\text { New } \\
\text { direction }\end{array}$ & $0.0 \%$ & $3.5 \%$ & $5.3 \%$ & $22.8 \%$ & $31.6 \%$ & $36.8 \%$ & 100 & 0.126 & 0.240 \\
\hline $\begin{array}{l}\text { Human } \\
\text { resources }\end{array}$ & $1.8 \%$ & $3.5 \%$ & $7.0 \%$ & $10.5 \%$ & $49.1 \%$ & $28.1 \%$ & 100 & 0.145 & 0.107 \\
\hline Equipment & $5.7 \%$ & $1.9 \%$ & $26.4 \%$ & $32.1 \%$ & $28.3 \%$ & $5.7 \%$ & 100 & 0.124 & 0.257 \\
\hline Marketing & $0.0 \%$ & $1.8 \%$ & $5.5 \%$ & $20.0 \%$ & $58.2 \%$ & $14.5 \%$ & 100 & $0.150^{\star *}$ & 0.087 \\
\hline
\end{tabular}

Source: author's calculations. ${ }^{*}$ significance on $p$-value $=0.05 ;{ }^{* *}$ significance on $p$-value $=0.1$.

The main focus on profit investment was allocation into human resources (most of the respondents preferred $80-100 \%$ of an amount) and marketing, which is in line with previous qualitative studies of Krejčí and Šebestová (2018) and Palová and Šebestová (2020) who examined investments into socially oriented innovations. A statistically significant relationship was found in marketing preference. Thirdly, we want to demonstrate the time and situational shift within the covid-19 situation. Table 3 compares the preference change to invest profit back. Unfortunately, there was found no statistically significant relationship.

The results support the primary goal of enterprises that focus on social goals when the reinvestment share is growing because of a lack of external resources during pandemic situations (mean value at $60 \%$ ). According to that, those enterprises have to change their preferences to be sure which segments will be more significant for their survival. The current situation is illustrated in Figure 1. 
Table 3 | Change in the investment share $(\mathrm{N}=57)$

\begin{tabular}{|c|c|c|c|c|c|c|c|c|}
\hline \multirow[b]{2}{*}{ Period } & \multicolumn{6}{|c|}{$\begin{array}{c}\text { How much profit do you reinvest back to your } \\
\text { enterprise? (in percentage share) }\end{array}$} & \multicolumn{2}{|c|}{ Evaluation } \\
\hline & $0 \%$ & $20 \%$ & $40 \%$ & $60 \%$ & $80 \%$ & $100 \%$ & $\begin{array}{c}\text { Cramer } \\
\mathrm{V}\end{array}$ & Sig. \\
\hline $\begin{array}{l}\text { A:Before } \\
\text { Covid-19 }\end{array}$ & $0.0 \%$ & $10.5 \%$ & $10.5 \%$ & $26.3 \%$ & $31.6 \%$ & $21.1 \%$ & 0.130 & 0.205 \\
\hline $\begin{array}{l}\text { B: During } \\
\text { Covid-19 }\end{array}$ & $9.4 \%$ & $1.6 \%$ & $7.8 \%$ & $18.8 \%$ & $34.4 \%$ & $28.1 \%$ & 0.096 & 0.48 \\
\hline Difference A-B & $-9.4 \%$ & $-8.6 \%$ & $-2.7 \%$ & $-7.5 \%$ & $2.8 \%$ & $7 \%$ & - & - \\
\hline
\end{tabular}

Source: author's calculations. ${ }^{*}$ significance on $\mathrm{p}$-value $=0.05{ }^{* *}$ significance on $\mathrm{p}$-value $=0.1$.

Figure 1 | Preferences in the investment portfolio

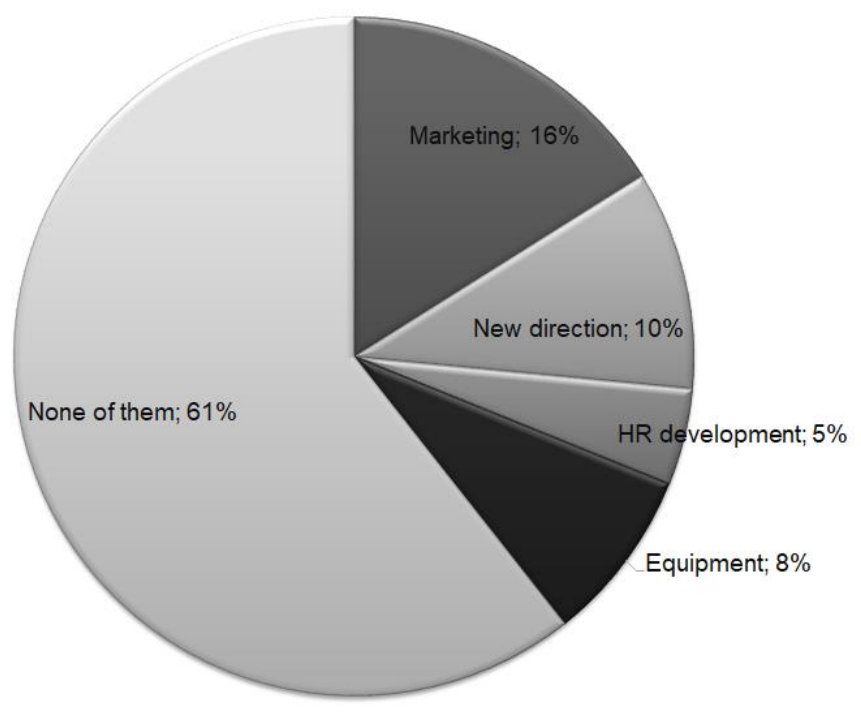

Source: author's illustration

Surprisingly, most respondents are satisfied with their financial portfolio, and they do not plan any changes during unstable business situations (61\%). Those enterprises know that they still require external resources, so marketing activities are significant in those hard times (an increase of $16 \%$ ). To be sure about the decision-making process of social enterprises, the change of investment behaviour was evaluated (Figure 2). 
Figure 2 | Changes in investment behaviour

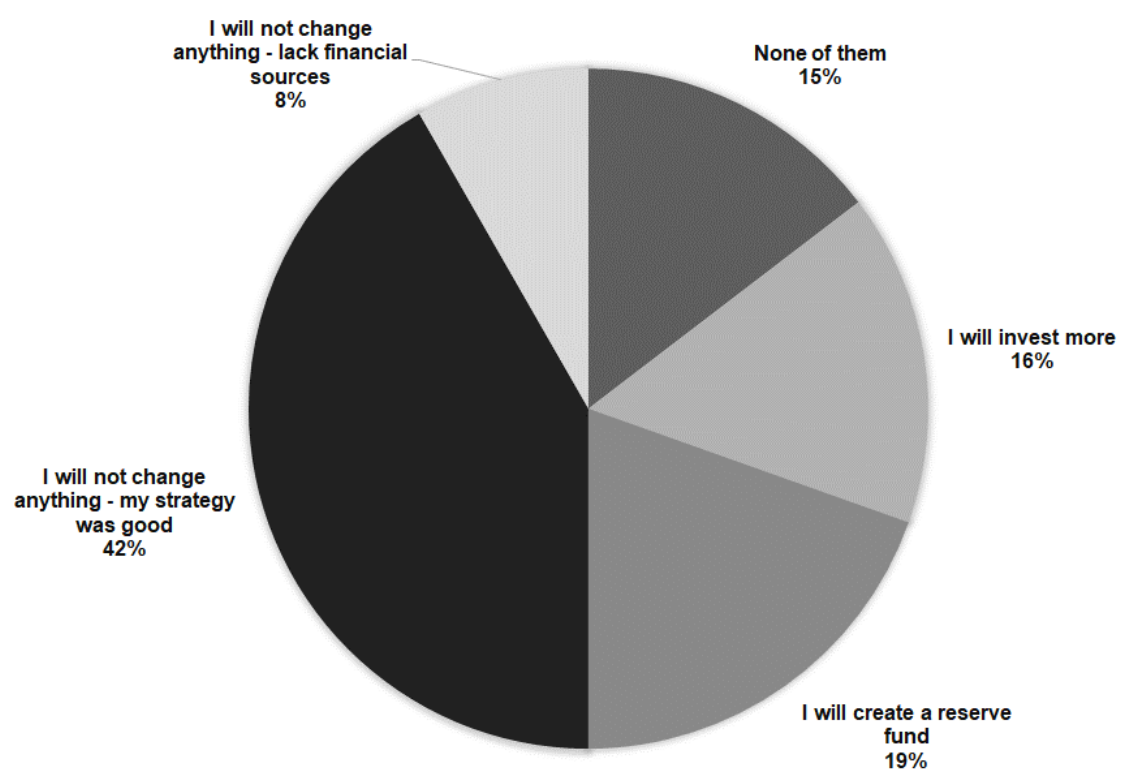

Source: author's illustration

As illustrated above, most of them will not change their behaviour at all (42\%) as a lesson learned from the current situation because they felt it was a good decision. On the other hand, the second group will be more active - will be investing more $(16 \%)$ or creating a new reserve fund for crisis (19\%). This behaviour extends the classification of social enterprises mentioned by Santos et al. (2015) when we add their reactive (investing more, reserve funds - in case of bridging hybrid, coupling hybrid enterprises) adaptive behaviour (good strategy, mainly market hybrids) or defensive (not change because of lack of funds, represented by blending hybrids).

The results have shown that examined social enterprises think very carefully about financial sources, and they do not risk the lack of funds and problems with providing their social mission to the community, as was stated in the research question. Crucial decisions in financial planning are an ongoing activity in social business, not just single activity caused by the Covid-19 situation.

Finally, we can answer two hypotheses. At first, $\mathrm{H} 1$ (During the Covid-19 pandemic situation; social entrepreneurs reinvest more profit into business activities) -hypothesis H1 was rejected. A comparison between those two situations (see Table 3) have shown that the share of respondents, who invest more than $80 \%$ of their profit increased by $9.8 \%$ in total, but the test did not find any significant effect (Cramer V =0.096, Sig. $=0.48$, $p$-value $=0.05$ ).

At second, $\mathrm{H} 2$ (Social entrepreneurs changed their financial planning due to the pandemic situation), was evaluated according to Figure 2 when $43 \%$ of examined entrepreneurs were satisfied with their financial strategy at all. The hypothesis $\mathrm{H} 2$ was rejected. 


\section{Conclusion}

The study contributes to the discussion about financial decision making in social enterprises when financial planning is mentioned as a part of the strategic plan. Most of the examined social enterprises continuously manage their financial resources, operational management, and a high degree of sensitivity to external factors, which supports the Bénabou and Tirole study (2010).

Thus, this case study supports the understanding of social enterprises within a nonstandard situation, such as Covid-19, when social entrepreneurs prefer to keep the same direction to safe labour positions as social goals (Gutterman, 2021).Discussions with social business owners have shown that decision-making is an everyday part of business management, and they do not consider whether to distinguish between its short-term and long-term impact. This behaviour is mainly due to the mix of funds, which are limited, for example, by the fiscal year (Roundy \& Bonnal, 2020). The results of the research showed new possibilities and information from the environment of these companies. Interestingly, the structure of reinvested earnings changes depending on the change in external conditions, although they should guarantee its amount of $51 \%$. Therefore, it is clear that some companies do not have to follow this rule regularly. At the same time, it turns out that social enterprises are sensitive to external changes and therefore create reserves. In order to prevent their decline, as current statistics show, it is necessary to support their strategic behaviour and financial planning. This goal can be achieved by building the skills and financial competencies of social entrepreneurs to be able to classify the main activities, not focus on marketing activities as "solo" activity (see Figure 1), but in connection with a proper fundraising plan to get external financial sources (Palová \& Šebestová, 2020; Zott et al., 2011).

Based on the results should be advised that each social enterprise conducted its analysis of reinvested earnings and compared the changes that have occurred. Financial decisions and planning have to be done continuously, as confirmed by the presented sample. Especially consider the benefits that social enterprises have realised that it is necessary to invest in marketing activities to acquire customers in any period and the context of a pandemic. It was even more critical - to find new ways to customers. From this perspective, it is necessary to keep what works, and as shown in Figure 2, support area, which provides businesses advantage - new directions - especially social innovation and marketing support already mentioned. We recognise three main areas of the financial decision process - main motive, behaviour and investment share.

\subsection{Motive for generated profit investments}

The research results show that social enterprises are most motivated to invest less risky. Social enterprises focus mainly on the benefits added to yields, payback period and financial ratios. Tax deductions, financial ratios and interest rates in the bank proved to be statistically significant (Table 1). These are safer forms of investment in social enterprises as part of investing. They are not affected by their social aspect. Economic factors mainly influence their investment motives in the company. It follows that social enterprises can indeed be considered hybrid enterprises, as they prove to be commercial enterprises in the field of investment, however, with the difference that the generated profit is returned to the company's operation. Therefore, the primary motivation for maximising the return on investment is to obtain additional resources for their activities. That is why they still adhere to 
the principles of responsible investment in their activities. However, one aspect of social entrepreneurship is also the economic aspect (TESSEA). This aspect is, therefore, significantly reflected in their investment behaviour. Less knowledge of financial resources and the social aspect built into social entrepreneurship goals can move these managers more towards safer investments. However, this is a possible research question for future research, as this relationship has not been explored.

\subsection{Investment behaviour}

Social enterprises are highly focused on their employees due to the social aspect of entrepreneurship, and due to this, a significant part of investments is directed to human resources. Marketing is also essential for social enterprises. Marketing activities support the sale of offered products and services. Thanks to this, social enterprises can also develop. Given that $42 \%$ of social enterprises do not need to change their investment behaviour, they can say that they are satisfied (Table 2).

Result also points to the situation with Covid-19, during which nothing has changed. Investment behaviour, therefore, has no demonstrable connection with the ongoing pandemic. Some companies needed to create a larger reserve fund during the pandemic to secure themselves from a similar risky situation better (Table 3).

\subsection{Change in the investment share}

Research in this area has not confirmed any statistically significant relationship between the investment share and its change during Covid-19. However, it can be noted that the results suggest an increase in the share of reinvestments. Although companies must return at least $50 \%$ of their profits to business, reinvestments are around $60 \%$ on average during a pandemic. This effect suggests the need for more certainty and a change in investment and reinvestment behaviour, where companies are increasing their reserve funds and investing more (Figure 2).

Both investment behaviour and investment share can also be related to the company's length in the market. Companies that are longer on the market may be more confident and have a reserve fund strategy. However, companies set up shortly before the pandemic have no certainty and therefore want to create them after the experience with Covid-19. However, these are questions for future research.

\subsection{Future research directions}

Research shows that factors are influencing financial decisions. Their decisions are based mainly on facts related to their business and financial situation, which is usually not very good. The question has arisen in which field of activity they did business if that part was affected by the situation associated with the pandemic.

Further research is required to find out how they need strategic planning differs in different phases of the social enterprise life cycle and how this situation affects financial decisions and the population's preferences in which the profit will be reinvested and in what amount (BuggLevine et al., 2012; Santos et al., 2015). Those results could be seen as significant for discussion only when respondents were from more than one-quarter of their number in the Czech Republic. 


\section{Acknowledgement}

This research was supported by the SGS grant "Smart Performance Dashboards in business practice" of Silesian University in Opava [SGS 14/2021].

\section{References}

Bacq, S. C., \& Janssen, F. (2011). The multiple faces of social entrepreneurship: A review of definitional issues based on geographical and thematic criteria. Entrepreneurship \& Regional Development, 23 (5-6), 373-403. https://doi.org/10.1080/08985626.2011.577242.

Battilana, J., \& Lee, M. (2014). Advancing Research on Hybrid Organizing - Insights from the Study of Social Enterprises. Academy of Management Annals, 8 (1), 397-441. https://doi.org/10.1080/19416520.2014.893615.

Bénabou, R., \& Tirole, J. (2010). Individual and corporate social responsibility. Economica, 77(305), 119. https://doi.org/10.1111/j.1468-0335.2009.00843.x.

Besley, T., \& Ghatak, M. (2017). Profit with purpose? A theory of social enterprise. American Economic Journal: Economic Policy, 9(3), 19-58. https://doi.org/10.1257/pol.20150495.

Borocki, J., Radisic, M., Sroka, W., Greblikaitè, J., \& Androniceanu, A. (2019). Methodology for strategic posture determination of SMEs. Inzinerine Ekonomika - Engineering Economics, 30(3), 265277. https://doi.org/10.5755/j01.ee.30.3.21966.

Bugg-Levine, A., Kogut, B., \& Kulatilaka, N. (2012). A new approach to funding social enterprises. Harvard Business Review, 90(1/2), 118-123.

Cavana, R., Delahaye, B., \& Sekeran, U. (2001). Applied Business Research: Qualitative and Quantitative. Australia: Wiley.

Christie, M. J., \& Honig, B. (2006). Social entrepreneurship: New research findings. Journal of World Business, 41 (1), 1-5.

Cohen, J. (1988). Statistical Power Analysis for the Behavioral Sciences. 2nd Edition. Routledge.

CSP. (2021). Adresář sociálních podniků. České sociální podnikání. Retrieved February 20, 2021, from https://www.ceske-socialni-podnikani.cz/adresar-socialnich-podniku.

Dohnalová, M. et al. (2009). Sociální ekonomika - vybrané otázky. Praha: Výzkumný ústav práce a sociálních věcí.

Duháček Šebestová, J., \& Krejčí, P. (2021). How Do Social Enterprises Deliver Tailored Support to Minority Entrepreneurs? In Cooney T.M. (ed). The Palgrave Handbook of Minority Entrepreneurship. Palgrave, 2021. pp. 439-463. https://doi.org/10.1007/978-3-030-66603-3_20.

Durieux, M. B., \& Stebbins, R. A. (2010). Social entrepreneurship for dummies. Wiley.

EMES. (2016). When the employment landscape is rapidly changing, what is the contribution of social enterprises? Retrieved February 20, 2020, from https://emes.net/news/when-the-employmentlandscape-is-rapidly-changing-what-is-the-contribution-of-social-enterprises/.

European Commission (1989). The Communication, 'business in the social economy sector: Europe's frontier-free market'. Retrieved February 20, 2021, from https://eur-lex.europa.eu/legalcontent/EN/TXT/?uri=celex\%3A51990AC1046.

European Commission (2011). Social Business Initiative (COM(2011) 682 final). Retrieved November 10, 2020, from http://eur-

lex.europa.eu/LexUriServ/LexUriServ.do?uri=COM:2011:0682:FIN:en:PDF 
Fowler, A. (2000). NGOS as a moment in history: beyond aid to social entrepreneurship or civic innovation? Third World Quarterly, 21(4), 637-654. https://doi.org/10.1080/713701063.

Gawell, M. (2014). Societal entrepreneurship and different forms of social enterprise. In Lundström, A., et al. (eds.) Social Entrepreneurship. Springer International Publishing, pp. 23-41.

Groot, A., \& Dankbaar, B. (2014). Does Social Innovation Require Social Entrepreneurship? Technology Innovation Management Review, 4(12), 17-26.

Gutterman, A. (2021). Sustainability Standards and Instruments. Business Expert Press.

Harding, R. (2004). Social enterprise: the new economic engine? Business Strategy Review, 15(4), 3943. https://doi.org/10.1111/j.0955-6419.2004.00338.x.

Hervieux, C., Gedajlovic, E., \& Turcotte, M. F. B. (2010). The legitimisation of social entrepreneurship. Journal of Enterprising Communities: People and Places in the Global Economy, 4(1), 37-67. https://doi.org/10.1108/17506201011029500.

Katz, R. A., \& Page, A. (2010). The Role of Social Enterprise. Vermont Law Review, 35, 59-103.

Kozma, T. (2017). Cooperation in the supply chain network. Forum Scientiae Oeconomia, 5(3), 45-58.

Krejčí, P., \& Šebestová, J. (2018). Social Innovation Ties: A Dilemma of Product and Employee Orientation. Polish Journal of Management Studies, 17(2), 123-133. https://doi.org/10.17512/pjms.2018.17.2.11.

Lahtinen, S., Kuusela, H., \& Yrjölä, M. (2018). The company in society: when corporate responsibility transforms strategy. Journal of Business Strategy, 39(4), 11-18. https://doi.org/10.1108/JBS-052017-0069.

Lin-Hi, N., Hörisch, J., \& Blumberg, I. (2015). Does CSR matter for non-profit organisations? Testing the link between CSR performance and trustworthiness in the non-profit versus for-profit domain. Voluntas, 26(5), 1944-1974. https://doi.org/10.1007/s11266-014-9506-6.

Lodsgård, L., \& Aagaard, A. (2017). Creating value through CSR across company functions and NGO collaborations: a Scandinavian cross-industry case study. Scandinavian Journal of Management, 33(3), 162-174.

Lortie, J., Cox, K. C., \& Roundy, P. T. (2017). Institutional channelling and social entrepreneurship opportunity recognition. Academy of Management Proceedings, 2017(1), 11018.

Mair, J., \& Martí, I. (2006). Social entrepreneurship research: A source of explanation, prediction, and delight. Journal of World Business, 41(1), 36-44. https://doi.org/10.1016/j.jwb.2005.09.002.

Martin, R. L., \& Osberg, S. (2007). Social Entrepreneurship: The Case for Definition. Stanford Social Innovation Review, Spring, 29-39.

Moravcikova, D., \& Kliestikova, J. (2017). Brand building with using phygital marketing communication. Journal of Economics, Business and Management, 5(3), 148-153. https://doi.org/10.18178/joebm.2017.5.3.503.

Mulgan, G. (2006). The Process of Social Innovation. Innovations: Technology, Governance, Globalization, 1 (2), 145-162. https://doi.org/10.1162/itgg.2006.1.2.145.

NESsT. (2019). Idea2Entrepreneur Tools Suite. [Retrieved November 19, 2019, from https://www.nesst.org/tools-for-entrepreneurs.

Nijhof, A. H. J., \& Jeurissen, R. J. M. (2010). The glass ceiling of Corporate social responsibility. International Journal of Social Policy, 30(11/12), 616-631. 
Paksiova, R. (2017). The Critical Analysis of Profit for its Allocation Decision-Making. Scientific Annals of Economics and Business, 64, S1, 41-56.

Palová, Z., \& Šebestová, J. (2020). Competencies, Skills, and Goals Needed for Social Enterprises: Case of the Czech Republic. In Šebestová, J. (eds.) Developing Entrepreneurial Competencies for Start-Ups and Small Business. IGI Global, pp. 109-128.

Pope, S., Bromley, P., Lim, A., \& Meyer, J. W. (2018). The pyramid of non-profit responsibility: The institutionalisation of organisational responsibility across sectors. Voluntas, 29(6), 1300-1314.

Popescu, Ch. R. G., \& Popescu, G.N. (2019). An exploratory study based on a questionnaire concerning green and sustainable finance, corporate social responsibility, and performance: Evidence from the Romanian business environment. Journal of Risk and Financial Management, 12 (4), 162. https://doi.org/10.3390/jrfm12040162.

Rahman, A., Sultana, N., \& Mizanur Rahman, M. (2020). CSR vs Social Business for Sustainable Development, Crowther, D. \& Seifi, S. (Ed.) Governance and Sustainability (Developments in Corporate Governance and Responsibility, Vol. 15), Emerald Publishing Limited, Bingley, pp. 113-130. https://doi.org/10.1108/S2043-052320200000015007.

Roundy, P. T., \& Bonnal, M. (2020). Social entrepreneurship and economic thought: A synthesis and path to rapprochement. Global Business and Economics Review, 23(3), 257-279. https://doi.org/10.1504/GBER.2020.110014.

Saeed, S., Yousafzai, S., Paladino, A., \& De Luca, L. M. (2015). Inside-out and outside-in orientations: a meta-analysis of orientation's effects on innovation and firm performance. Industrial Marketing Management, 47, 121-133.

Sanek Ponte. (2015). Výsledky průzkumu vedení a ř́zení NNO v roce 2015. Retrieved January 19, 2021, from https://adoc.pub/zprava-o-vedeni-a-izeni-nestatnich-neziskovych-organizaci-v07bb9c302d4048d3b546fafa85cdc2534784.html.

Santos, F., Pache, A. C., \& Birkholz, C. (2015). Making hybrids work: Aligning business models and organisational design for social enterprises. California Management Review, 57(3), 36-58. https://doi.org/10.1525/cmr.2015.57.3.36.

Sebestova, J., Sperka, R., Malecka, J., \& Luczka, T. (2017). Co-working centres as a supportive network for cross border business cooperation. Forum Scientiae Oeconomia, 5(4), 23-34.

Šedivý, M., \& Mendlíková, O. (2011). Úspěšná nezisková organizace. Grada Publishing.

Trivedi, C. (2010). Towards a social ecological framework for social entrepreneurship. Journal of Entrepreneurship, 19(1), 63-80. https://doi.org/10.1177/097135570901900104.

Tucker, S. (2014). Social Innovation for Public Service Excellence. UNDP Global Centre for Public Service Excellence. Retrieved November 19, 2019, from http://www.undp.org/content/dam/uspc/docs/GPCSE_Social\%20Innovation.pdf.

Zott, C., Amit, R., \& Massa, L. (2011). The business model: recent developments and future research. Journal of Management, 37(4), 1019-1042. https://doi.org/10.1177/0149206311406265.

The research article passed the review process. | Received: June 23, 2021; Revised: September 8, 2021; Accepted: October 7, 2021; Pre-published online: December 17, 2021; Published in the regular issue: July 18, 2022. 